\title{
Metabolites in the milk of buffalo, Holstein cross, indigenous and Red Chittagong cattle of Bangladesh
}

\author{
MA I slam* ${ }^{1}$, ME Uddin ${ }^{1}$, R J ahan ${ }^{2}$, A Wadud ${ }^{1}$, MM Sarkar ${ }^{3}$ \\ ${ }^{1}$ Department of Dairy Science; ${ }^{2}$ Department of Animal Science, Bangladesh Agricultural University, \\ Mymensingh 2202, Bangladesh; ${ }^{2}$ PKSF, Agargaon, Dhaka, Bangladesh
}

\begin{abstract}
Low molecular weight chemical compounds or intermediate products of a metabolism or other cellular processes are called metabolites. The objective of the present study was to investigate the variations in the metabolite concentration in the milk from crossbred water Buffalo (B), Holstein cross (H), Indigenous cattle (I) and Red Chittagong Cattle (R) and the relationships among those metabolites. The concentration of citric acid, a -keto glutaric acid (a-keto GA), orotic acid, pyruvic acid, succinic acid, lactic acid, formic acid, uric acid and propionic acid were measured by using High Performance Liquid Chromatography. Pooled milk samples of nine B, fifteen I and twenty R cows were collected from the research farm of Bangladesh Livestock Research Institute, Savar, Dhaka, Bangladesh. The pooled milk samples of $\mathrm{H}$ were collected from twenty five cows of Central Cattle Breeding Station and Dairy Farm, Savar, Dhaka, Bangladesh. All the sampling was done from the morning milking. The samples were preserved by adding 'bronopol tablet' and frozen and stored at $-20{ }^{\circ} \mathrm{C}$. Except propionic acid, all the metabolites varied significantly $(p<0.01)$ among the milk types and B milk had lowest concentration of them. The highest concentration of citric acid (ppm) was $2245.50 \pm 39.90$ in I milk followed by $2156.60 \pm 26.60$ in $R, 1858.30 \pm 8.70$ in $H$ and $1366.70 \pm 33.70$ in B milk. The $H, I$ and R milk were found similar in their a-keto GA content. Similarities were also found for succinic acid between $H$ and $R$ milk and so for $\mathrm{H}$ and $\mathrm{I}$ milk in uric acid content. Highest formic acid was found in $\mathrm{H}$ milk $(392.78 \pm 2.23 \mathrm{ppm})$ and the lowest was $308.91 \pm 3.75$ ppm in R milk while B and I milk was found similar. The lowest concentration of uric acid was found $0.44 \pm 0.26 \mathrm{ppm}$ in B milk and $\mathrm{R}$ milk had the highest content (11.38 $\pm 1.10 \mathrm{ppm})$. Pyruvic, formic and propionic acids showed no significant relationship among them and with others as well. The most highly significant $(p<0.01)$ correlation was found between orotic and a-keto GA $(r=0.915)$ and between uric and succinic acid $(r=0.914)$. So, the metabolites showed a considerable variation in their concentration in different types of milk and also some of the parameters showed significant relationship among them.
\end{abstract}

Key words: Buffalo, Cattle, Metabolites, Milk

Bangladesh Animal Husbandry Association. All rights reserved. Bang. J. Anim. Sci. 2013.42 (2): 152-157

\section{Introduction}

Milk, a complex biologicalfluid, is the secretion of mammals for the nourishment and development of neonate. It contains water, lipids, carbohydrates, proteins, vitamins and minerals. In addition to these major constituents of milk, different variety of compounds are also present in milk which include pigments, flavor compounds, metabolites (organic acids, nucleotides etc.) and so on. Metabolites are the chemical intermediates or products of a metabolism or other cellular processes. Milk metabolites may originate from multiple cell types or metabolisms, and the different sources of metabolites may contribute to the variations of milk metabolite concentrations. Microorganisms may also secrete metabolites in milk (Hettinga et al. 2008; Hettinga et al. 2009). Shennan and Peaker (2000) reported that metabolites may come from live or dead somatic cells, or from the mammary epithelial cells. Moreover, metabolites may result from an enzymatic reaction in the milk (Azzara and Dimick 1985) or may be transferred to milk from blood due to increased permeability of the endothelial cell membrane (Bannerman 2009).

A number of organic acids are known to present in milk, including lactic acid, citric acid, orotic 


\section{Islam et al. (2013) Bang. J. Anim. Sci. 42 (2): 152- 157}

acid, sialic acid, sorbic acid etc. They are important due to their preservative properties. Together with other biologically active compounds in milk, such as immunoglobulin's, lysozyme and lactoferrin, they prevent the growth of various microorganisms in milk (Monk et al. 1995; Lui et al. 1995), maintaining the quality of a product during storage. They are the part of the milk buffering capacity, hence are related with $\mathrm{pH}$ dependent milk processing like cheese and yoghurt. Citric acid is also used as a substrate by the starter culture to produce the flavor compounds.

Faulkner (1980) proposed that the metabolites concentrations in milk reflect their concentration in Golgi vesicles and cytoplasm. They found similarities between milk and mammary tissue concentration of some of the metabolites. And conclude that study of such a minor components may help to follow mammary gland metabolism in vivo and will also provide additional data on secretory mechanisms.

Since, the metabolites arises from the cellular processes, genetic makeup of the animal, changes in the physiological condition of the animal, diet etc. may also have influence on their concentration. Faulkner et al. (1982) reported the influence of onset and cessation of lactation on the metabolites concentration in goat milk. In another study, Faulkner et al. (1989) found dietary effects on the concentration of some metabolites in cow's milk.

The milk produced in Bangladesh has not been studied well for their minor components. The dairy animals are generally undernourished, poor producer of milk and obviously different (genetically) from other well studied breed/types of dairy animals. The metabolites index may give a good indication about the physiological condition of the animals and also about the quality of milk. So this will be a benchmark study from Bangladesh perspective. Thus, the objective of the study was to investigate the variation of different metabolites (citric acid, a-keto glutaric acid, orotic acid, pyruvic acid, succinic acid, lactic acid, formic acid, uric acid and propionic acid) in milk of crossbred water Buffalo (B), Holstein cross (H), Indigenous cattle (I) and Red
Chittagong Cattle ( $R$ ) milk and the relationship among the metabolites.

\section{Materials and Methods}

Pooled milk sample of nine B cows were collected from the buffalo farm of Bangladesh Livestock Research Institute, Savar, Dhaka, Bangladesh. Milk of fifteen I and twenty $R$, respectively, were also taken from the same institute dairy farm. The pooled milk sample of $\mathrm{H}$ was collected from twenty five cows of Central Cattle Breeding Station and Dairy Farm, Savar, Dhaka, Bangladesh. All the samples were taken from the morning milk. Since, it was pooled milk sample, it includes milk from animals at different number and stages of lactation. The samples were preserved by adding bronopol tablet ( $D \& F$ control systems, Inc. USA; 1 tablet $/ 40 \mathrm{~mL}$ milk) immediately after milking, in CellStal ${ }^{(\mathrm{R})}$ tubes followed by freezing and stored at $-20{ }^{\circ} \mathrm{C}$ until analyzed.

Daily milk production of $\mathrm{B}, \mathrm{H}, \mathrm{I}$ and $\mathrm{R}$ milking cows during the sampling was 1.5 to $3.0 \mathrm{~L}, 2.5$ to $8.5 \mathrm{~L}, 2.5$ to $5.8 \mathrm{~L}$ and 1.3 to $5.0 \mathrm{~L}$, respectively. The B were supplied with approximately $4 \mathrm{~kg}$ rice straw with $0.250 \mathrm{~kg}$ of molasses/head/day, approximately $4 \mathrm{~kg}$ of concentrate mixture/ head/day composed of wheat bran, khesari bran, wheat crushed, oilcake, fish meal, salt and premix at a ratio of $3.0,0.75,0.30,0.20,0.04$, 0.125 , and 0.075 , respectively. The $\mathrm{I}$ and $\mathrm{R}$ cattle were fed on the same ration. They were offered with approximately $3 \mathrm{~kg}$ of concentrate mixture (wheat bran, khesari bran, sesame oil cake, soybean oil cake, crushed oyster shell, Crushed corn, and common salt at a ratio of 140 $25,15,20,5,7.5$ and 1, respectively)/head/day. The B, I and R were also supplied with German (Echinochloa grousgalli) and Napier (Pennisetum purpureum) grasses. They were also allowed grazing on various types of roadside grasses (non-descriptive). The $\mathrm{H}$ cows were fed on approximately $2.75 \mathrm{~kg}$ concentrate mixture (wheat bran, broken maize, khesari, soyabean, Di-calcium phosphate and salt at a ratio of 50 , $15,15,17,2$ and 1 , respectively /head/day) for first $3 \mathrm{~L}$ of milk and then additional $0.5 \mathrm{~kg}$ for every additional liter of milk and were also supplied with German (Echinochloa grousgalli) 


\section{Metabolites in the milk}

Napier (Pennisetum purpureum), oat (Avena sativa) and para (Brachiaria mutica) grasses.

The concentration of citric acid, a-keto GA, orotic acid, pyruvic acid, succinic acid, lactic acid, formic acid, uric acid and propionic acid were measured by using High Performance Liquid Chromatography (HPLC) according to the method described by Narvhus et al. (1998) with some modifications. The analysis was done at IKBM, UMB, 1432-Ås, Norway. In brief, milk was diluted by miliQ water (Millex ${ }^{\circledR}$ AA $0.8 \mu \mathrm{m}$ filter unit, Millipore Corp. Carrightwohill co. cork, Ireland) at a ratio of $1: 2.5(\mathrm{w}: \mathrm{v})$. After adding $200 \mu \mathrm{L} 0.5 \mathrm{M}$ sulfuric acid $\left(\mathrm{H}_{2} \mathrm{SO}_{4}\right)$ and $8.0 \mathrm{~mL}$ acetonitril $\left(\mathrm{CH}_{3} \mathrm{CN}\right.$, Merck KGaA, Germany), the whole content was mixed for 30 minutes on a multifix mixing machine. Then, it was centrifuged at 3500 rpm for 15 minutes at room temperature. The supernatant was filtered (Acrodisc ${ }^{\circledR}$ CR $13 \mathrm{~mm}$ syringe filter with $0.2 \mu \mathrm{m}$ PTFE membrane, HPLC certified, PALL life sciences) and collected in a HPLC vial. Aminex HPX-87H column (Bio-Rad laboratories, Hercules, CA) was used for the analysis. Which was connected to a Perkin Elmer Series 200 pump (Perkin Elmer, Waltham, MA), a Perkin Elmer series 200 auto sampler and a Perkin Elmer LC oven 101 and the column was held at $30{ }^{\circ} \mathrm{C}$. Five milli molar $\mathrm{H}_{2} \mathrm{SO}_{4}$ was used as mobile phase with a flow rate of $0.4 \mathrm{~mL} / \mathrm{min}$. All the metabolites were identified compared to the retention times of the standards (all from Sigma) using Perkin Elmer series 200 UV/VIS detector.

All the samples were run in triplicate. One Way ANOVA and Pearson Correlation (with ' $p$ ' values) were done by using statistical analytical software Minitab 16. ANOVA was coupled with Tukey's test that gives mean separation in case of significant difference among the samples.

\section{Results and Discussion}

The major organic acid in raw milk was citric acid (Belitz \& Grosch, 1999). Our results showed that citric acid concentration of milk varied significantly $(p<0.001 ;$ Table 1$)$. The highest value was observed in I milk (2245.50 239.90 ppm) followed by $R(2156.60 \pm 26.60 \mathrm{ppm})$ and $\mathrm{H}$ milk (1858.30 $\pm 8.70 \mathrm{ppm})$ and lowest amount was found in B milk (1366.70 $\$ 33.70 \mathrm{ppm})$. Fox and McSweeney (1988) found 1750 ppm citric 154 acid in milk which is comparable with $\mathrm{H}$ milk and is mostly bound to calcium or magnesium. The differences here indicate the genetic influence because $\mathrm{I}$ and $\mathrm{R}$ cows received same diet but vary in their citric acid concentration. However, diet is also important and Hess et al (1920) found less citric acid in the milk from animal fed on more concentrate. Dellaglio (1988) said that fermentation of milk decreases the concentration of citric acid in milk and similar result was also found by Driessen \& Puhan (1988). In contrast, our milk samples were well preserved (no lactic acid development). So, fermentative variation is not confounded here. Concentration of citric acid may also vary with changes in the rate of fatty acid synthesis within the mammary gland (Faulkner and Pollock, 1989). And these milk vary in their fat content and fatty acid composition (results not included).

The results are given in Table 1 . The a-keto GA and orotic acid concentration in milk differed significantly $(p<0.001)$. Mean separation revealed that Buffalo milk had lowest a-keto GA (28.64 $\pm 0.33 \mathrm{ppm})$ and cattle milk were found similar. This acid is also known as

2-oxogluterate. Faulkner and Pollock (1989) found a decrease of it with the reduced output of short and medium chain fatty acids. The concentration of a-keto GA in milk also indicative to the reproductive physiology of the cow as Faulkner et al. (1982) reported that concentration of a-keto GA increased rapidly at parturition and reach the peak at about 2 days and after 4 days it starts to reduce. Our animals are on different stage of lactations so the variation is mainly because of the genetic makeup and corresponding physiology of the animals.

Orotic acid is the pyrimidinecarboxylic acid and according to Robinson (1980), it is virtually the only component in the acid soluble nucleotide fraction of bovine milk. All the milk samples in the present study showed significant $(p<0.001)$ difference. The highest concentration was $59.52 \pm 0.31 \mathrm{ppm}$ in $\mathrm{H}$ milk which was almost three times of $B$ milk content of orotic acid. Motyl et al. (1991) reported $0.618 \pm 0.233 \mathrm{mmol} / \mathrm{L}$ as the concentrations of orotic acid in polish black and white bred cow's milk. This is very much 


\section{Islam et al. (2013) Bang. J. Anim. Sci. 42 (2): 152- 157}

similar to our $\mathrm{H}$ milk, reflecting the similarity of temperate blood. They also observed higher concentration in younger cow and its increase during the development of lactation. Robinson (1980) also reported stage of lactation as a factor of orotic acid concentration and he also found cow to cow variation. The $\mathrm{H}$ milk was also found similar to Jesse et al. (1980) who conclude that orotic acid concentration in milk varied due to some extent by breed, number of lactations, and stage of lactation of cows.

It is interesting that we were able to quantify pyruvic acid only in buffalo milk (Table 1). It may be that the concentration in cow's milk was lower than the limit of detection/quantification. The absence of lactic acid (Table 1) was expected because we used bronopol to preserve the milk and no microbial growth was expected in the presence of bronopol tablet. It also signifies that the metabolites we are discussing here all are from the animal, since there was no bacterial growth in the milk.

Succinic acid also known as acid of amber, produced and participates mainly in TCA cycle. Succinic acid content of milk showed significant $(p<0.001$; Table 1$)$ ) variation among the type of animal. The highest value was found in $R$ (265.14 $3.78 \mathrm{ppm}$ ) followed by I and the lowest value was for $B(160.39 \pm 11.43 \mathrm{ppm})$ milk and $\mathrm{H}$ and $R$ milk were found similar $(p>0.05)$.

The lowest amount of formic acid was found in the milk of $\mathrm{R}$ preceded by $\mathrm{I}$ and $\mathrm{B}$ milk and the highest was for $\mathrm{H}$ genotype (Table 1 ). The formic acid content differed significantly $(p<0.001)$ among the genotype except $\mathrm{I}$ and B milk. They did not differ significantly $(p>0.05)$ between them.

The results are given in Table 1 . Uric acid is a purine derivative. Uric acid concentration of $\mathrm{B}$ milk was less than $1.00 \mathrm{ppm}$ while I and $\mathrm{H}$ milk contained 6.00-8.00 ppm and R milk was found to contain even higher (11.38 ppm). The difference was found significant $(p<0.001)$ but I and $H$ didn't differ $(p>0.05)$ in their uric acid content. Sikka et al. (2001) found 1.34 to 4.45 $\mu \mathrm{g} / \mathrm{ml}$ uric acid in buffalo milk and found no effect of diet. Gieseck et al. (1994) reported that milk uric acid varies with milk production. And animals under our study also have different milk production from each other. Propionic acid is important for the ruminants as they maintain blood glucose level by gluconeogenesis from propionic acid. So during the secretion of milk, along with other metabolites, propionic acid may also get into the milk. We found no difference ( $p>0.05$ ) among $B, H, I$ and $R$ milk in their propionic acid content.

The correlations among the metabolites studied are given in Table 2. Citric acid had shown significant positive correlation with a-keto GA $(0.702)$, orotic $(0.586)$, succinic $(0.596)$ and uric acid (0.826).

Table 1. Concentration (ppm) of metabolites in Buffalo (B), Holstein Cross (H), Indigenous (I) and Red Chittagong Cattle (R) milk.

\begin{tabular}{cccccc}
\hline & Buffalo & Holstein cross & Indigenous & Red Chittagong & $p$ \\
\hline Citric acid & $1366.70^{\mathrm{D}} \pm 33.70$ & $1858.30^{\mathrm{C}} \pm 8.70$ & $2245.50^{\mathrm{A}} \pm 39.90$ & $2156.60^{\mathrm{B}} \pm 26.60$ & 0.000 \\
a-keto GA & $28.64^{\mathrm{B}} \pm 0.33$ & $69.30^{\mathrm{A}} \pm 3.41$ & $61.16^{\mathrm{A}} \pm 9.28$ & $56.46^{\mathrm{A}} \pm 8.31$ & 0.000 \\
Orotic acid & $20.79^{\mathrm{D}} \pm 0.55$ & $59.52^{\mathrm{A}} \pm 0.31$ & $43.54^{\mathrm{B}} \pm 0.41$ & $41.79^{\mathrm{C}} \pm 0.05$ & 0.000 \\
Pyruvic acid & $2.79 \pm 0.02$ & n.d. & n.d. & n.d. & - \\
Succinic acid & $160.39^{\mathrm{C}} \pm 11.43$ & $258.45^{\mathrm{A}} \pm 15.47$ & $202.56^{\mathrm{B}} \pm 3.07$ & $265.14^{\mathrm{A}} \pm 3.78$ & 0.000 \\
Formic acid & $343.97^{\mathrm{B}} \pm 6.32$ & $392.78^{\mathrm{A}} \pm 2.23$ & $338.91^{\mathrm{B}} \pm 0.86$ & $308.91^{\mathrm{C}} \pm 3.75$ & 0.000 \\
Uric acid & $0.44^{\mathrm{C}} \pm 0.26$ & $8.20^{\mathrm{B}} \pm 0.75$ & $6.92^{\mathrm{B}} \pm 1.09$ & $11.38^{\mathrm{A}} \pm 1.10$ & 0.000 \\
Propionic acid & $203.58 \pm 20.83$ & $216.46 \pm 22.48$ & $199.86 \pm 15.66$ & $175.78 \pm 20.08$ & 0.168 \\
\hline
\end{tabular}

ppm, parts per million; p, probability; GA, Glutaric acid; n.d., not detected; $p=0.00$ ), significant at $<1 \%$; Means with different superscripts within the same row differ significantly 


\section{Metabolites in the milk}

Table 2. Correlation among citric acid, a-keto Glutaric acid (a-keto GA), orotic acid, pyruvic acid, succinic acid, formic acid, uric acid and propionic acid concentration in milk.

\begin{tabular}{lllllllll}
\hline & $\begin{array}{l}\text { Citric } \\
\text { acid }\end{array}$ & $\begin{array}{l}\text { a-keto } \\
\text { GA }\end{array}$ & $\begin{array}{l}\text { Orotic } \\
\text { acid }\end{array}$ & $\begin{array}{l}\text { Pyruvic } \\
\text { acid }\end{array}$ & $\begin{array}{l}\text { Succinic } \\
\text { acid }\end{array}$ & $\begin{array}{l}\text { Formic } \\
\text { acid }\end{array}$ & $\begin{array}{l}\text { Uric } \\
\text { acid }\end{array}$ & $\begin{array}{l}\text { Propionic } \\
\text { acid }\end{array}$ \\
\hline Citric acid & & & & & & & \\
a-keto GA & $0.702^{*}$ & & & & & & \\
Orotic acid & $0.586^{*}$ & $0.915^{* * *}$ & & & & & \\
Pyruvic acid & 0.889 & -0.765 & 0.767 & & & & \\
Succunic acid & $0.596 *$ & $0.735^{* *}$ & $0.793^{* *}$ & 0.365 & & & \\
Formic acid & -0.303 & 0.314 & 0.518 & 0.864 & 0.075 & & \\
Uric acid & $0.826 *$ & $0.692^{*}$ & $0.713^{* *}$ & 0.698 & $0.914 * * *$ & -0.186 & \\
Propionic acid & -0.310 & 0.220 & 0.180 & -0.674 & -0.202 & 0.623 & -0.409 \\
\hline
\end{tabular}

$*$, significant at $5 \% ; * *$, significant at $1 \% ; * * *$, significant at $<1 \%$

The a-keto GA found significantly correlated with orotic (0.915), succinic (0.735) and uric acid (0.692). Orotic acid had also significant positive correlation with succinic (0.793) and uric acid (0.713). Succinic acid and uric acid are also correlated (0.914) significantly. Dellaglio (1988) showed a positive correlation between the concentration of citric and orotic acid in milk. Citric acid, succinic acid and a-keto GA are the members of the same TCA cycle and that's may explain their positive correlation. Pyruvic, formic and propionic acid showed no significant correlations among them and with others.

\section{Conclusion}

Buffalo milk had the lowest concentration of most of the metabolites. Maximum four metabolites ( $a$ keto glutaric, orotic, succinic and formic acid) were found highest in Holstein cross milk. Milk of Red Chittagong Cattle was found rich in a-keto glutaric, succinic and uric acid and Indigenous cattle was in citric and a-keto glutaric acid. It can be concluded that the metabolites concentration in milk may also vary from species to species and among breeds within the same species. Citric, aketo glutaric, orotic, succinic and uric acid showed strong correlations among them.

\section{Acknowledgement}

We are grateful to Professor GE Vegarud, IKBM, UMB, 1432-Ås, Norway for providing the laboratory facilities. Our thanks is also to Bangladesh Livestock Research Institute, Central Cattle Breeding Station and Dairy Farm, Savar, 156
Dhaka, Bangladesh and Department of Livestock Services, Ministry of Fisheries and Livestock, GOB, Farmgate, Dhaka, Bangladesh for their kind necessary actions regarding the sampling of milk.

\section{References}

Azzara CD, Dimick PS (1985). Lipolytic enzyme activity of macrophages in bovine mammary gland secretions. Journal of Dairy Science, 68: 1804-1812.

Bannerman DD (2009). Pathogen-dependent induction of cytokines and other soluble inflammatory mediators during intramammary infection of dairy cows. Journal of Animal Science, 87 (supplementary): 10-25.

Belitz HD, Grosch W (1999). Milk and dairy products. In: Food Chemistry (eds. MM Burghagen, D Hadziyev, P Hessel, S Jordan, C Sprinz). Springer-Verlag, Berlin, Heidelberg, New York, P. 470-512.

Dellaglio F (1988). Starters for fermented milks. Bulletin IDF, P. 227, 27-34.

Driessen FM, Puhan Z (1988). Technology of mesophilic fermented milk. Bulletin IDF, P. 227, 75-81

Faulkner A (1980). The presence of cellular metabolites in milk. Biochimica et Biophysica Acta, 630: 141-145.

Faulkner A, Blatchford DR, White JM, Peaker M (1982). Changes in the concentrations of metabolites in milk at the onset and cessation of lactation in the goat. Journal of Dairy Research, 49: 399-405. 
Islam et al. (2013) Bang. J. Anim. Sci. 42 (2): 152- 157

Faulkner A, Pollock HT (1989). Changes in the concentration of metabolites in milk from cows fed on diets supplemented with soybean oil or fatty acids. Journal of Dairy Research, 56: 179-183.

Fox PF, McSweeney PLH (1998). Dairy chemistry and biochemistry. Blackie Academic \& Professional Publishers, London.

Gieseck DL, Ehrentreich L, Stanassinger M (1994). Mammary and renal excretion of purine metabolites in relation to energy intake and milk yield in dairy cows. Journal of Dairy Science, 77: 2376

Hess AF, Unger LJ, Supplee, GC (1920). Relation of fodder to the antiscorbutic potency and salt content of milk. Journal of Biological Chemistry, 14: 229.

Hettinga $K$, van Valenberg $H$, Lam $T$, van Hooijdonk A (2009). The origin of the volatile metabolites found in mastitis milk. Veterinary Microbiology, 137: 384-387.

Hettinga KA, van Valenberg HJF, Lam TJGM, van Hooijdonk ACM (2008). Detection of mastitis pathogens by analysis of volatile bacterial metabolites. Journal of Dairy Science, 91: 3834-3839.

Jesse BW, Anderson CR, Robinson JL (1980). Bovine Milk Orotate: Differences between Cows and Changes during Lactation. Journal of Dairy Science, 63: 235-242.

Lui X, Yousef AE, Chism GW (1995). Inactivation of Escherichia coli 0157: $\mathrm{H7}$ by the combination of antimicrobial organic acids and pulsed electric fields. IFT Annual Meeting, P. 29, 17.

Monk JD, Beuchat L, Hathcox AK (1995). Inhibitory effects of sucrose fatty acids esters, alone and in combination with EDTA and organic acids on Lysteria monocytogenes and Staphylococcus aureus. J ournal of Food Protection, 58: 9- 10.

Motyl T, Krzemiński J, Podgurniak M, Witeszczak C, Zochowski P (1991). Variability of orotic acid concentration in cow's milk. Endocrine regulations, 25: 79-82.

Narvhus JA, Østeraas K, Mutukumira T, Abrahamsen RK (1998). Production of fermented milk using malty compoundproducing strain of Lactococcus lactis spp. Lactis biovar. Diacetylactis, isolated from Zimbabwean naturally fermented milk. International J ournal of Food Microbiology, 41: $73-80$.

Robinson JL (1980). Bovine Milk Orotic Acid: Variability and Significance for Human Nutrition. Journal of Dairy Science, 63: 865-871.

Shennan DB, Peaker M (2000). Transport of milk constituents by the mammary gland. Physiology Review, 80: 925-951.

Sikka P, Saxena NK, Gupta R, Lall D (2001). Studies on milk allantoin and uric acid in relation to feeding regimens and production performance in buffaloes. AsianAustralasian J ournal of Animal Science, 14: 1634- 1637. 